\title{
An Investigation of the Wild Rat Crown Incisor as an Indicator of Lead (Pb) Exposure Using Inductively Couple Plasma Mass Spectrometry (ICP-MS) and Laser Ablation ICP-MS
}

\author{
Andrew Kataba ${ }^{1,2}{ }^{\mathbb{D}}$, Shouta M. M. Nakayama ${ }^{1, *}$, Hokuto Nakata ${ }^{1} \mathbb{D}$, Haruya Toyomaki ${ }^{1}$, Yared B. Yohannes ${ }^{1,3}$, \\ John Yabe ${ }^{2}$, Kaampwe Muzandu ${ }^{2}$, Golden Zyambo ${ }^{2}$, Ayano Kubota ${ }^{4}$, Takehisa Matsukawa ${ }^{4}$ (D), \\ Kazuhito Yokoyama ${ }^{4}$, Yoshinori Ikenaka ${ }^{1,5}$ and Mayumi Ishizuka ${ }^{1, *}$
}

Citation: Kataba, A.; Nakayama, S.M.M.; Nakata, H.; Toyomaki, H.; Yohannes, Y.B.; Yabe, J.; Muzandu, K.; Zyambo, G.; Kubota, A.;

Matsukawa, T.; et al. An Investigation of the Wild Rat Crown Incisor as an Indicator of Lead $(\mathrm{Pb})$ Exposure Using Inductively Couple Plasma Mass Spectrometry (ICP-MS) and Laser Ablation ICP-MS. Int. J. Environ. Res. Public Health 2021, 18, 767. https://doi.org/10.3390/ ijerph18020767

Received: 24 November 2020 Accepted: 13 January 2021 Published: 18 January 2021

Publisher's Note: MDPI stays neutral with regard to jurisdictional claims in published maps and institutional affiliations.

Copyright: (c) 2021 by the authors Licensee MDPI, Basel, Switzerland. This article is an open access article distributed under the terms and conditions of the Creative Commons Attribution (CC BY) license (https:// creativecommons.org/licenses/by/ $4.0 /)$
1 Laboratory of Toxicology, Department of Environmental Veterinary Sciences, Faculty of Veterinary Medicine, Hokkaido University, Kita 18 Nishi 9, Kita-ku, Sapporo 060-0818, Japan; andrewkataba@gmail.com (A.K.); hokuto.nakata@vetmed.hokudai.ac.jp (H.N.); yahahuhru@gmail.com (H.T.); ybyared@gmail.com (Y.B.Y.); y_ikenaka@vetmed.hokudai.ac.jp (Y.I.)

2 School of Veterinary Medicine, The University of Zambia, P.O. Box 32379, Lusaka 10101, Zambia; mjyabe@yahoo.co.uk (J.Y.); kmuzandu@yahoo.com (K.M.); goldzgambo@gmail.com (G.Z.)

3 Department of Chemistry, College of Natural and Computational Science, University of Gondar, P.O. Box 196, Gondar 6200, Ethiopia

4 Department of Epidemiology and Environmental Health, Faculty of Medicine, Juntendo University, 2-1-1 Hongo, Bunkyo-ku, Tokyo 113-8421, Japan; ay-kubota@juntendo.ac.jp (A.K.); tmatsuka@juntendo.ac.jp (T.M.); kyokoya@juntendo.ac.jp (K.Y.)

5 Water Research Group, School of Environmental Sciences and Development, North-West University, Private Bag X6001, Potchefstroom 2531, South Africa

* Correspondence: shoutanakayama0219@gmail.com (S.M.M.N.); ishizum@vetmed.hokudai.ac.jp (M.I.); Tel./Fax: +81-11-706-5105 (S.M.M.N.)

Abstract: Lead $(\mathrm{Pb})$ is a metal toxicant of great public health concern. The present study investigated the applicability of the rat incisor in $\mathrm{Pb}$ exposure screening. The levels of lead in teeth $(\mathrm{Pb}-\mathrm{T})$ in the crown and root of incisors in laboratory Pb-exposed Sprague Dawley rats were quantified using inductively coupled plasma mass spectrometry (ICP-MS). The crown accumulated much $\mathrm{Pb}-\mathrm{T}$ than the root of the Sprague Dawley rat incisor. The levels of lead in blood (Pb-B) were positively correlated with the $\mathrm{Pb}-\mathrm{T}$ in the crown and root incisors of the Sprague Dawley rats. As an application of the $\mathrm{Pb}-\mathrm{T}$ crown results in experimental rats, we subsequently analyzed the $\mathrm{Pb}-\mathrm{T}$ in the crown incisors of $\mathrm{Pb}$-exposed wild rats (Rattus rattus) sampled from residential sites within varying distances from an abandoned lead-zinc mine. The $\mathrm{Pb}-\mathrm{T}$ accumulation in the crown of incisors of $R$. rattus rats decreased with increased distance away from the $\mathrm{Pb}-\mathrm{Zn}$ mine. Furthermore, the $\mathrm{Pb}-\mathrm{T}$ was strongly correlated $(r=0.85)$ with the Pb levels in the blood. Laser ablation ICP-MS Pb-T mappings revealed a homogenous distribution of $\mathrm{Pb}$ in the incisor with an increased intensity of $\mathrm{Pb}-\mathrm{T}$ localized in the tip of the incisor crown bearing an enamel surface in both Sprague Dawley and R. rattus rats. These findings suggest that $\mathrm{Pb}-\mathrm{T}$ in the crown incisor may be reflective of the rat's environmental habitat, thus a possible indicator of $\mathrm{Pb}$ exposure.

Keywords: lead; incisor; biomarker; sentinel; wild rodent

\section{Introduction}

Lead $(\mathrm{Pb})$ is a toxic metal known to cause a number of physiological and biochemical dysfunctions in animals and humans [1]. Although Pb poisoning has considerably receded in developed countries [2], chronic exposure to low levels of $\mathrm{Pb}$ remains a perennial phenomenon in some developing countries. A case in point is Kabwe town in Zambia, with a lead-zinc mine history legacy characterized by an alarming $\mathrm{Pb}$ poisoning in adults and children living near the closed lead-zinc mine [3-5]. Moreover, acute fatal cases of $\mathrm{Pb}$ poisoning in over 400 children in Nigeria [6] and 18 children in Dakar, Senegal [7] linked 
to anthropogenic activities have been reported. Even at low non-fatal levels, $\mathrm{Pb}$ exposure causes cognitive impairments in children exposed in early life stages [2]. In adults, low cumulative $\mathrm{Pb}$ exposure has been linked to renal, cardiovascular, and reproductive-systemrelated disorders [8,9]. Bellinger et al. [8] further revealed that early stage $\mathrm{Pb}$ exposure in children led to disadvantaged adult outcomes such as poor academic performance and low income. Thus, biomarkers of $\mathrm{Pb}$ exposure that are reliable and easy to obtain from humans and sentinel animals that share habitats with humans are required [10].

Traditionally, $\mathrm{Pb}$ in blood ( $\mathrm{Pb}-\mathrm{B})$ has been widely used as a biomarker for $\mathrm{Pb}$ exposure in humans [11,12]. However, $\mathrm{Pb}-\mathrm{B}$ poses a short mean biological life of only around $30-40$ days and may only reflect primarily both ongoing steady-state exposures and relatively recent exposures [10]. Moreover, changing the conditions of exposure causes a $\mathrm{Pb}-\mathrm{B}$ variation and typically the blood $\mathrm{Pb}$ level reverts to normal once the exposure ceases [13]. In contrast, the concentration of $\mathrm{Pb}$ in teeth $(\mathrm{Pb}-\mathrm{T})$ is a cumulative function of earlier exposure which allows for the identification of historic undetected cases of $\mathrm{Pb}$ exposure even after the other indices have returned to normal [14]. Although the $\mathrm{Pb}-\mathrm{T}$ in the whole tooth has been considered as a biomarker of $\mathrm{Pb}$ exposure in children [15] and rodents [16], the distribution $\mathrm{Pb}$ within is not even. The uneven distribution of $\mathrm{Pb}$ in teeth may be due to different dental structures and the level of calcification of the dental parts [12].

The use of laser ablation inductively coupled plasma mass spectrometry (LA-ICP-MS) as a technique has been applied to estimate the distribution patterns of metals in the dentine and enamel parts of the teeth [17-19]. However, there are limited reports on the distribution or mapping of $\mathrm{Pb}$ in rodent incisor teeth of wild or laboratory rats exposed to $\mathrm{Pb}$. Therefore, further investigations using techniques for advanced mapping of distribution $\mathrm{Pb}$ in teeth such as LA-ICP-MS are needed.

Wild rodents have been used as sentinel animals and biomonitors of environmentalrelated pollution assessments of pesticides [20], asbestos [21], and heavy metal pollution [22]. In the present study, the rodent incisor tooth was investigated in laboratory and wild rodents as an indicator of $\mathrm{Pb}$ exposure. We hypothesized that $\mathrm{Pb}$ accumulates differently within the incisor teeth and that the part with much accumulation may be sampled as a biomarker of $\mathrm{Pb}$ exposure. To the best of our knowledge, the quantification of $\mathrm{Pb}-\mathrm{T}$ in the root and crown subdivisions of incisor teeth in $\mathrm{Pb}$-exposed laboratory rats and the use of the incisor crown of wild rats as an indicator of $\mathrm{Pb}$ exposure has never been reported. Lead distribution mappings were performed using LA-ICP-MS in both laboratory and wild rats exposed to $\mathrm{Pb}$ to augment the $\mathrm{Pb}$ - $\mathrm{T}$ quantification done using ICP-MS and ascertain the distribution of $\mathrm{Pb}$ in rodent incisor. The purpose of this study was to evaluate the accumulation pattern of lead in the crown and root incisor teeth of laboratory rats following lead exposure. Based on the laboratory rat results that showed high levels of $\mathrm{Pb}$ in the crown incisor, the study explored the use of the wild rat crown incisor as an indicator of lead exposure in a field situation. Furthermore, the distribution pattern of lead in rodent incisor using laser ablation inductively coupled plasma mass spectrometry was evaluated.

\section{Materials and Methods}

\subsection{Laboratory Animals and Exposure}

Animal experiments were performed at the Faculty of Veterinary Medicine, Hokkaido University under the supervision and with the endorsement of the Institutional Animal Care and Use Committee of Hokkaido University, Sapporo, Japan (approval number: 16-0017). Male Sprague Dawley rats $(n=18)$ aged seven weeks were purchased from Sankyo Labo Service Corporation, Inc. (Tokyo, Japan). The rats were kept in six lead-free polypropylene cages in community housing of three rats ( $n=3$ per cage). The animals were acclimated to the animal facility for one week prior to $\mathrm{Pb}$ exposure with access to lead-free food (rodent chow, Labo MR Stock, Nosan Corporation, Yokohama, Japan) and distilled water ad libitum. There were no significant body weight differences among all the groups. Two cages with six $(n=6)$ rats were randomly assigned to the three 
exposure levels (control, low, and high dosage exposure). Two different concentrations of $\mathrm{Pb}$ acetate, $100 \mathrm{mg} / \mathrm{L}$ and $1000 \mathrm{mg} / \mathrm{L} \mathrm{Pb}$ (Wako Pure Chemical Industries, Osaka, Japan), were given through drinking water for eight weeks to the low and high dosage groups, respectively. The control group received only distilled water for the same period. The choice of $\mathrm{Pb}$ levels of exposure for the current study was based on the previous study in mice that had a dose-dependent $\mathrm{Pb}$ tissue accumulation at $100 \mathrm{mg} / \mathrm{L}$ and $1000 \mathrm{mg} / \mathrm{L}$ lead acetate concentrations [23]. At the end of the exposure period, rats were euthanized under carbon dioxide with sevoflurane. Blood and incisors teeth (upper and lower) were collected following extraction. For uniformity, we assigned the upper and lower incisors on the left side of the jaws for quantitative $\mathrm{Pb}$ analysis using inductively coupled plasma mass spectrometry (ICP-MS), and those on the right side were assigned for qualitative $\mathrm{Pb}$ mapping using LA-ICP-MS for each individual rat across all the groups. The blood and teeth samples were collected in lead-free polypropylene tubes and were kept at $-80{ }^{\circ} \mathrm{C}$ and $-20{ }^{\circ} \mathrm{C}$ prior to analysis, respectively.

\subsection{Wild Rat Sampling and Species Identification}

The sampling was done with permission and strict adherence to the guidelines from the Zambian Ministry of Fisheries and Livestock, as well as the Faculty of Veterinary Medicine, Hokkaido University, Sapporo, Japan (approval number: Vet-17010). Wild rats were collected from Kabwe, Zambia, a town known for extensive Pb environmental contamination $[4,5,24,25]$ between June and July 2017. Kabwe is situated at approximately $142^{\circ} 70^{\prime} \mathrm{S}$ and $28^{\circ} 260^{\prime}$ E. Four residential townships in Kabwe, namely, Lukanga (LK), Makululu (MK), Chowa (CH), and Mutwe Wansofu (MW) were used as sampling sites for wild rats based on their relative distances to the closed lead-zinc $(\mathrm{Pb}-\mathrm{Zn})$ mine. Six $(n=6)$ wild rats were captured using live traps as previously described by our research group [25] from each of the four sites within varying distance from the closed $\mathrm{Pb}-\mathrm{Zn}$ mine. The furthest distance away from the closed mine in Lukanga (LK; $5.90 \mathrm{~km}$ ) was used as the control site. The other sites closer to the closed mine were taken as exposed sites, namely, Makululu (MK; $2.11 \mathrm{~km})$, Chowa $(\mathrm{CH} ; 0.86 \mathrm{~km})$, and Mutwe Wansofu (MW; $0.81 \mathrm{~km}$ ), respectively. The sampling sites were located and identified (Figure 1) using a global positioning system (GPS). The rats were euthanized with sevoflurane and blood and incisors teeth (lower) were collected following extraction. The samples were then immediately stored at $-20^{\circ} \mathrm{C}$ before being transported to the Faculty of Veterinary Medicine, Hokkaido University Sapporo, Japan under the cold chain systems. The transportation of samples was done in accordance with the international sample passage certificate from the Ministry of Fisheries and Livestock, Zambia (No. 11614). At Hokkaido University, the blood and teeth samples were stored at $-80^{\circ} \mathrm{C}$ and $-20^{\circ} \mathrm{C}$ in a deep freezer, respectively, until analysis. The species of the wild rats were identified using the genomic DNA sequencing method previously described by Robins et al. [26], and only rats that were of Rattus rattus species (Supplementary Materials, Table S1) were used in the current study. After the exclusion of the non- $R$. rattus rat species from the six $(n=6)$ rats trapped from each site, the final sample sizes were $n=2(\mathrm{LK}), n=5(\mathrm{CH}), n=5(\mathrm{MK})$, and $n=3(\mathrm{MW})$, respectively. A detailed description of the methods of species identification can be found in Appendix A. 


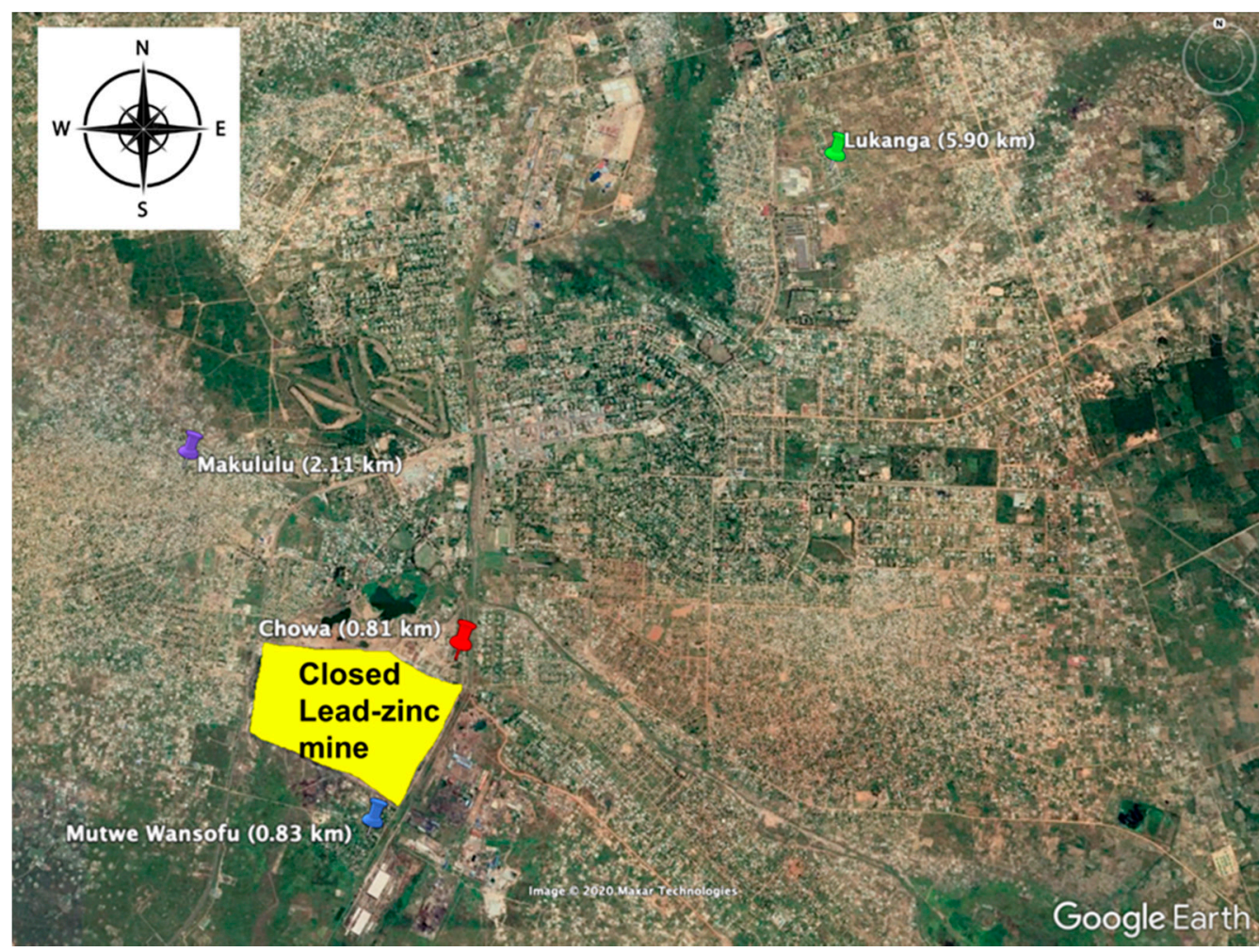

Figure 1. Sampling sites for wild rats. Mutwe Wansofu (MW; $n=6)$, Chowa $(\mathrm{CH} ; n=6)$, Makululu $(\mathrm{MK} ; n=6)$, and Lukanga $(\mathrm{LK} ; n=6)$. The closed $\mathrm{Pb}-\mathrm{Zn}$ mine is shown with a "yellow" shape.

\subsection{Digestion and Quantitative Analysis of Lead in Blood and Teeth Subdivisions}

$\mathrm{The} \mathrm{Pb}$ concentration in the blood and incisors teeth collected from the laboratory exposed Sprague Dawley rats and the $R$. rattus rats from Kabwe, Zambia were quantified. In the current study, blood and teeth were digested using the microwave acid method previously described by Nakata et al. [27,28] with minor modifications. To minimize surface contamination and remove excess blood, the teeth were firstly cleaned using an ultrasonic bath method as described by Ishii et al. [29] with some modifications. Briefly, the teeth samples were placed in an ultrasonic bath of L-cysteine (Cica reagent, $100 \mathrm{mg} / \mathrm{L}$; Kanto Chemical, Tokyo, Japan) for $5 \mathrm{~min}$ followed by rinsing in an ultrasonic bath of distilled water for $10 \mathrm{~min}$ prior to drying. The samples were then dried in an oven at $54{ }^{\circ} \mathrm{C}$ for $48 \mathrm{~h}$. Each tooth was divided into two subdivisions using the yellow-orange pigmentation of enamel on the crown part of the labial surface of the tooth [30] as a distinguishing reference mark as illustrated in Figure 2. Each lower (L) incisor was divided into two subdivisions, namely, L1 (root) and L2 (crown). The L1 is a part of the tooth that is embedded in the jawbone and L2 for the part tooth visible in the oral cavity. Similarly, the upper (U) incisor was divided into two subdivisions, namely, U1 (root) for the upper part of the tooth embedded in the jawbone and U2 (crown) for the part tooth visible in the oral cavity in live rodents as shown in Figure 2. In the case of the blood sample digestion, $0.1 \mathrm{~mL}$ of the blood were measured and put in pre-washed digestion vessels. To the vessels was added $5 \mathrm{~mL}$ of nitric acid (atomic absorption spectrometry grade, 30\%; Kanto Chemical, Tokyo, Japan), and $1 \mathrm{~mL}$ of hydrogen peroxide (Cica reagent, $30 \%$; Kanto Chemical, Tokyo, Japan) in readiness for digestion. The sample digestion was done using a ramped temperature program in a closed microwave system (Speed Wave MWS-2 microwave digestion system; Berghof, Eningen, Germany). The microwave system operating conditions used are given in the Supplementary Materials Table S2. Following cooling, the sample solutions were transferred into $15 \mathrm{~mL}$ polypropylene tubes and diluted to a final volume of $10 \mathrm{~mL}$ with ultra-distilled and de-ionized water. 
A.

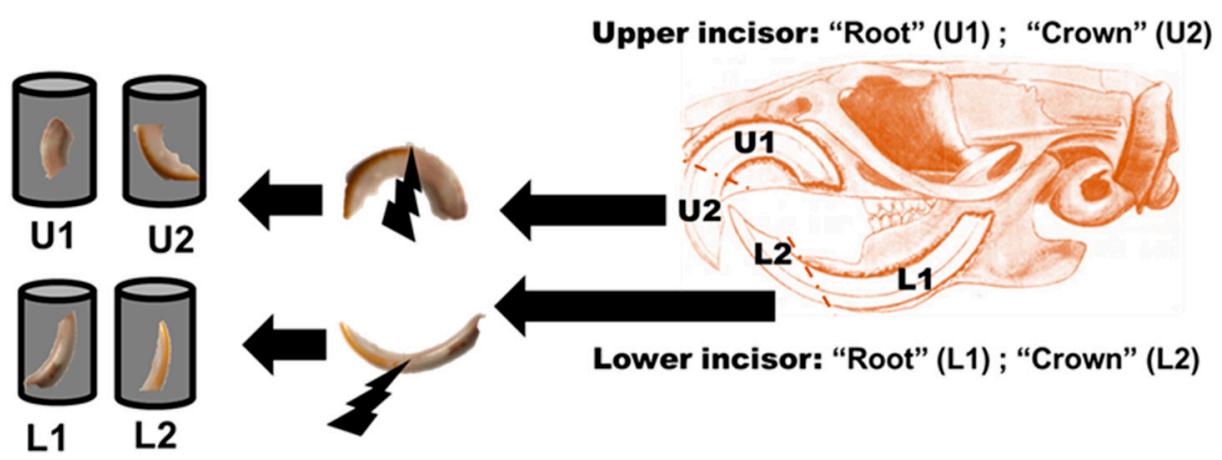

B.

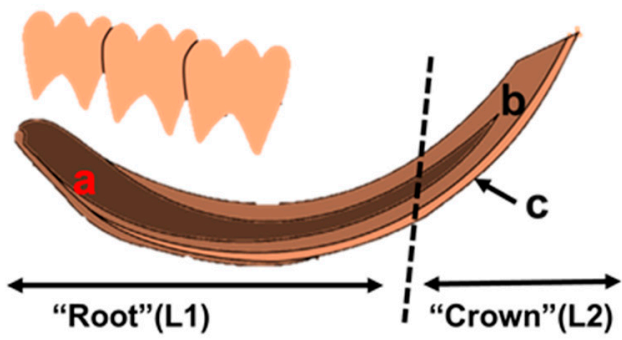

Figure 2. Divisions of the incisor teeth and schematic illustration of the longitudinal section of the incisor tooth. (A) Lower and upper incisor tooth divisions based on the yellow-orange enamel for microwave acid digestion. For upper incisors, the root (U1) part is anchored in the maxillary bone, and the crown (U2) part of the tooth is seen externally. Similarly, for lower incisors, the root (L1) part is anchored in the mandibular bone, and the crown (L2) part of the tooth is seen externally. (B) Illustrated schematic longitudinal section modified from Park et al. [31] of lower incisor tooth as was sectioned for direct LA-ICP-MS analysis. Furthermore, the three major parts of the incisor tooth are seen-(a) dental pulp, (b) dentine, and (c) enamel running only in the front part of the tooth. The dotted line is the imaginary division line used based on the obvious discoloration of enamel on the crown part of the tooth.

The $\mathrm{Pb}$ concentration quantification was performed using the ICP-MS (7700 series; Agilent Technologies, Tokyo, Japan), as described by Nakata et al. [28,29] with minor modifications. The operating conditions of ICP-MS were as given in the Supplementary Table S3. The quality control was performed by analysis of DOLT-4 (dogfish liver) (National Research Council of Canada, Ottawa, Canada) certified reference material. Replicate analysis of the reference material gave good recovery rates ranging from $95 \%$ to $105 \%$. The detection limit for $\mathrm{Pb}$ was $0.001 \mathrm{mg} / \mathrm{L}$.

\subsection{Laser Ablation Inductively Coupled Plasma Mass Spectrometry (LA-ICP-MS) Analysis of Incisor Teeth of Sprague Dawley and R. rattus Rats}

The incisor teeth samples from laboratory and $\mathrm{x}$ Pb-exposed wild rats were processed and analyzed according to the method previously described by Ishii et al. [29] with some minor modifications. Briefly, excess tissues and surface contamination of the teeth were cleaned using an ultrasonic bath of L-cysteine for 5 min followed by cleaning in an ultrasonic bath of distilled water and drying at $54{ }^{\circ} \mathrm{C}$ for $48 \mathrm{~h}$. Samples were sliced into $\sim 40 \mu \mathrm{m}$ sections along the longitudinal axis with a diamond blade and polished. The teeth sections were systematically scanned by a focused laser beam with the following parameters-spot diameter: $100 \mu \mathrm{m}$, scan speed: $70 \mu \mathrm{m}$ /sec using LA (NWR213; ESI, Portland, OR, USA)ICP-QQQ-MS (8800 series; Agilent Technologies) (Agilent Technologies, Inc., Santa Clara, CA, USA). Detailed analytical conditions are presented in Table S4. We reconstructed two-dimensional images from time-resolved analysis data of LA-ICP-MS by iQuant2, as 
described by Suzuki et al. [32], an in-house developed software. This software shows the localization of elements.

\subsection{Data Analysis}

The data analysis was performed using GraphPad Prism software (Prism 7 for Windows; Version 5.02, GraphPad Software, Inc., CA, USA) and reported as mean and standard deviation (SD). The data were first tested for normality using Kolmogorov-Smirnov test. The data was not normally distributed. We log-transformed the data for statistical analyses and retained the original values in the results and figures for easier interpretation and comparisons with other studies. We applied one analysis of variance (ANOVA) and multiple Tukey's comparison test as post hoc tests. In the present study, the difference between groups was deemed to be significant at $p<0.05\left(^{*}\right)$ and highly significant at $p<0.01\left(^{* *}\right)$. Log transformation of $\mathrm{Pb}$ concentrations was also done for the Pearson's correlations analysis between $\mathrm{Pb}-\mathrm{B}$ concentration and $\mathrm{Pb}-\mathrm{T}$ levels. The graphical representations were compiled using GraphPad Prism software.

\section{Results}

3.1. Lead in Blood (Pb-B) and Incisors Subdivisions of Laboratory-Exposed Sprague Dawley Rats

The $\mathrm{Pb}-\mathrm{B}$ levels increased significantly with the increase in the dose of $\mathrm{Pb}$ given through water with the high $\mathrm{Pb}$ group having the highest mean concentration of $39.63 \pm 8.09 \mu \mathrm{g} / \mathrm{dL}$, followed by the low $\mathrm{Pb}$ group, which had a mean of $9.90 \pm 1.71 \mu \mathrm{g} / \mathrm{dL}$ and the control had lowest with $4.01 \pm 0.86 \mu \mathrm{g} / \mathrm{dL}$ (Figure $3 \mathrm{~A}$ ). Both the high $\mathrm{Pb}$ and low $\mathrm{Pb}$ groups accumulated significantly higher $\mathrm{Pb}$ levels $(p<0.01)$ when compared to the control (Figure $3 \mathrm{~A})$. Further, the $\mathrm{Pb}-\mathrm{B}$ levels between the low and high groups were also significantly different $(p<0.05)$.

The accumulation of $\mathrm{Pb}$ in the teeth subdivisions $(\mathrm{Pb}-\mathrm{T})$ in $\mathrm{L} 1$ and $\mathrm{L} 2$ of lower and $\mathrm{U} 1$ and $\mathrm{U} 2$ upper incisors are shown in Figure $3 \mathrm{~B}, \mathrm{C}$, respectively. The accumulation $\mathrm{Pb}-\mathrm{T}$ in both subdivisions of the lower incisors was in a $\mathrm{Pb}$ dose-dependent manner with the high $\mathrm{Pb}$ group accumulating higher $\mathrm{Pb}-\mathrm{T}$ than the low $\mathrm{Pb}$ group and the control. The $\mathrm{Pb}-\mathrm{T}$ in the $\mathrm{L} 2$ was significantly higher (Tukey test, $p<0.01$ ) than that of $\mathrm{L} 1$ for both low $\mathrm{Pb}$ and high $\mathrm{Pb}$ groups. At low $\mathrm{Pb}$, the Pb-T in L1 was $4.72 \pm 2.10 \mathrm{mg} / \mathrm{kg}$, and L2 had $90.17 \pm 13.57 \mathrm{mg} / \mathrm{kg}$. At high $\mathrm{Pb}$ exposure, $\mathrm{L} 1 \mathrm{had} 33.07 \pm 15.51 \mathrm{mg} / \mathrm{kg}$, and L2 had $132.40 \pm 47.33 \mathrm{mg} / \mathrm{kg} \mathrm{Pb}-\mathrm{T}$, respectively. Similarly, $\mathrm{Pb}-\mathrm{T}$ accumulation in the upper incisors and their subdivisions accumulated in $\mathrm{Pb}$ dose-dependent manner. The $\mathrm{Pb}-\mathrm{T}$ in the $\mathrm{U} 1(6.79 \pm 2.03 \mathrm{mg} / \mathrm{kg})$ was significantly lower $(p<0.01)$ than $\mathrm{U} 2(42.44 \pm 16.58 \mathrm{mg} / \mathrm{kg})$ in the low $\mathrm{Pb}$ group. Likewise, in the high $\mathrm{Pb}$ group, the U1 $(26.13 \pm 11.63 \mathrm{mg} / \mathrm{kg})$ accumulated lower Pb-T than U2 (63.32 $\pm 24.89 \mathrm{mg} / \mathrm{kg})$. In addition, we observed that $\mathrm{L} 2$ or $\mathrm{U} 2$ at lower exposure accumulated significantly higher $\mathrm{Pb}-\mathrm{T}$ than the L1 or $\mathrm{U} 1$ at high exposure (Figure 3B,C). 


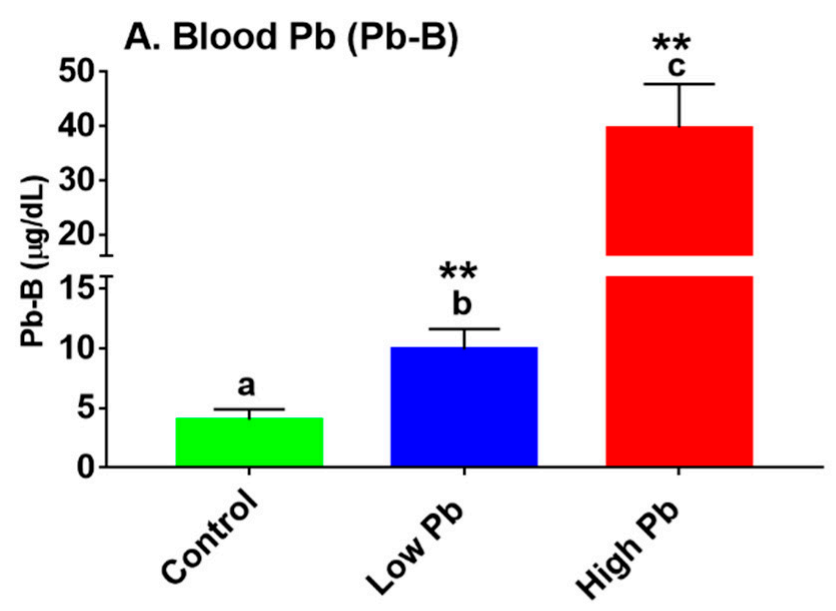

\section{B. Teeth $\mathrm{Pb}$ - lower incisors}

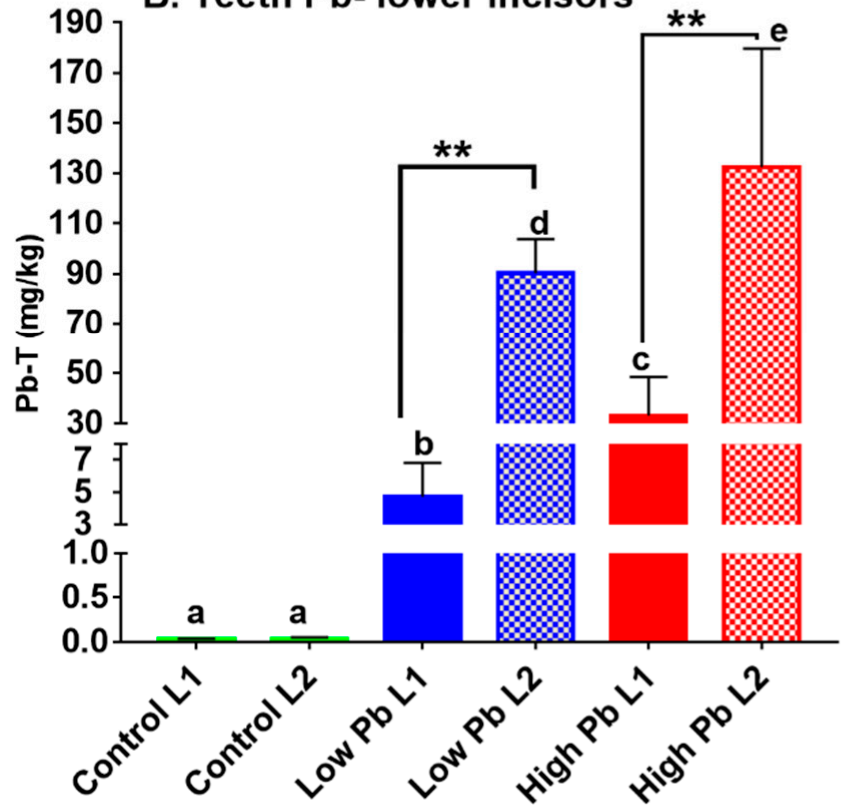

C. Teeth $\mathrm{Pb}$ - upper incisors

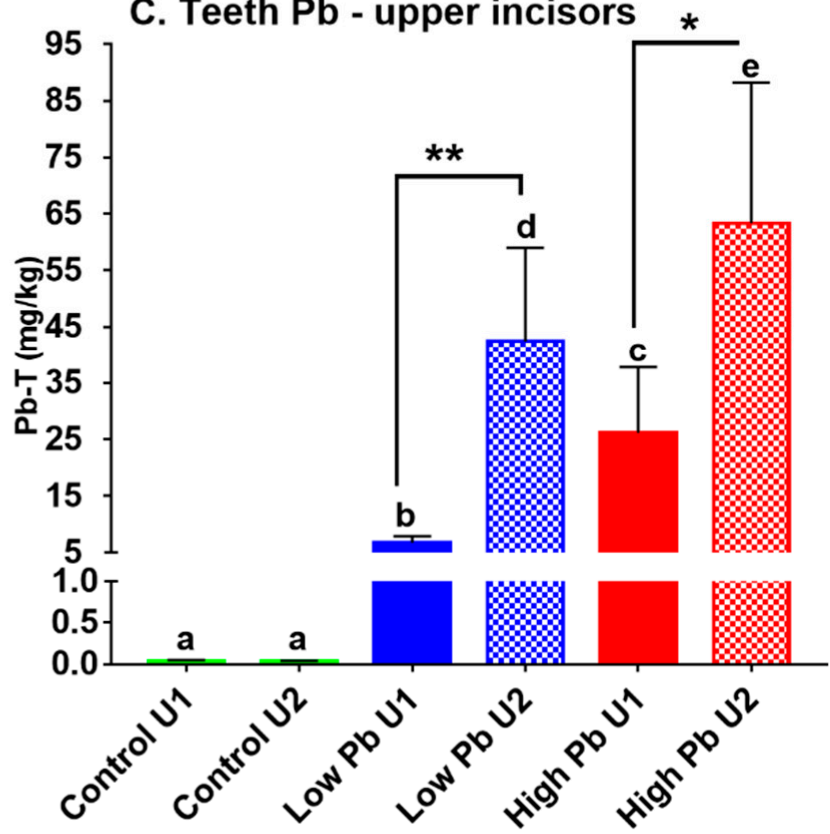

Figure 3. Mean $\pm \mathrm{SD}$ of $\mathrm{Pb}-\mathrm{B}$ and $\mathrm{Pb}-\mathrm{T}$ of laboratory $\mathrm{Pb}$ exposed Sprague Dawley rats. (A) Pb-B in control $(n=6)$, low $\mathrm{Pb}$ (100 mg/L Pb; $n=6)$, and high Pb (1000 mg/L Pb; $n=6) ;(\mathbf{B}) \mathrm{Pb}-\mathrm{T}$ in the lower incisor divisions (L1 and L2) and; (C) Pb-T in the upper incisor divisions ( $\mathrm{U} 1$ and $\mathrm{U} 2$ ). The lower-case letters $\mathrm{a}, \mathrm{b}, \mathrm{c}, \mathrm{d}$, and e represent significant differences among the groups using Tukey's multiple comparison test $(p<0.05)$. For the $\mathrm{Pb}-\mathrm{B},{ }^{* *}$ at $p<0.01$ represents a significant difference between the control and exposure groups, and for the $\mathrm{Pb}-\mathrm{T},{ }^{*}$ at $p<0.05$ and ${ }^{* *}$ at $p<0.01$ represent a significant difference between the crown and root of incisor teeth in each group Turkey's test.

\subsection{Relationship between Incisor Teeth Parts Pb and Blood Pb in the Laboratory Exposed Sprague Dawley Rats}

Figure 4 shows the relationship between the $\mathrm{Pb}-\mathrm{T}$ in the lower and upper incisors root and crown subdivisions with the $\mathrm{Pb}-\mathrm{B}$ concentration in the laboratory Sprague Dawley rats. In the present study, positive log-transformed Pearson's correlations between the $\mathrm{Pb}-\mathrm{B}$ and $\mathrm{Pb}-\mathrm{T}$ across all the exposed groups in the root and crown of the lower and upper incisors were observed. Much stronger correlations between $\mathrm{Pb}-\mathrm{T}$ and $\mathrm{Pb}-\mathrm{B}$ were recorded in the root of both lower and upper incisors than in the crown. The correlations were significant, namely, lower incisor (L1) Pb-T versus $\mathrm{Pb}-\mathrm{B}(r=0.91, p<0.01)$, lower incisor (L2) $\mathrm{Pb}-\mathrm{T}$ versus $\mathrm{Pb}-\mathrm{B}(r=0.82, p<0.01)$, upper incisor (U1) $\mathrm{Pb}-\mathrm{T}$ versus $\mathrm{Pb}-\mathrm{B}(r=0.91, p<0.01)$, and upper incisor (U2) Pb-T versus Pb-B $(r=0.85, p<0.01)$, as shown in Figure 4A-D. 
A. Blood Vs Teeth Pb - (L1)

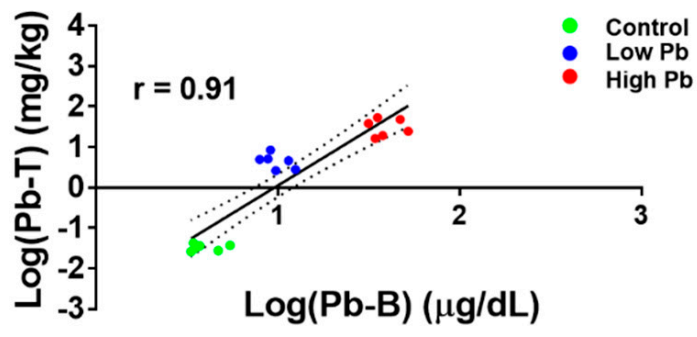

C. Blood Vs Teeth Pb - (U1)

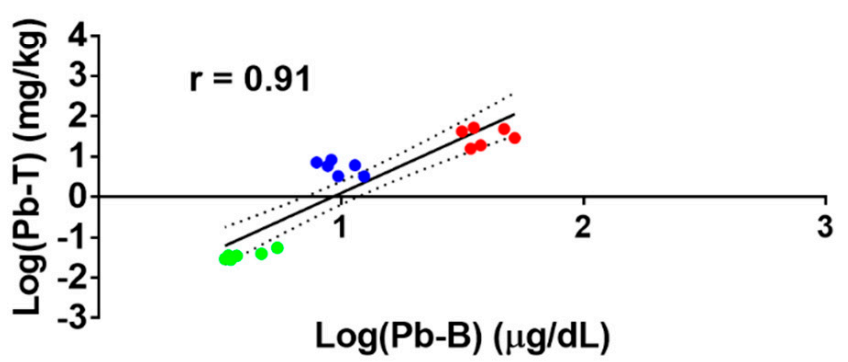

B. Blood Vs Teeth Pb - (L2)

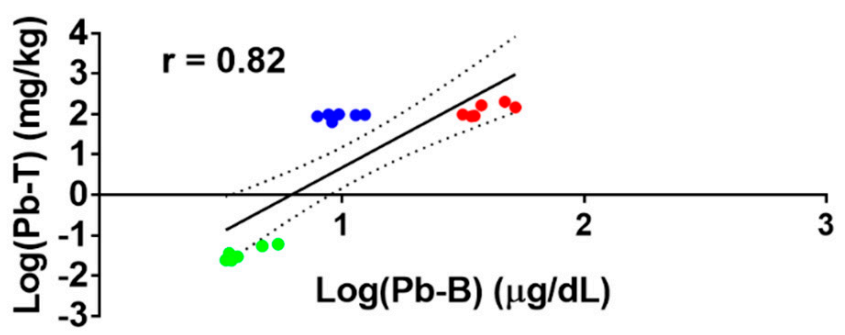

D. Blood Vs Teeth Pb - (U2)

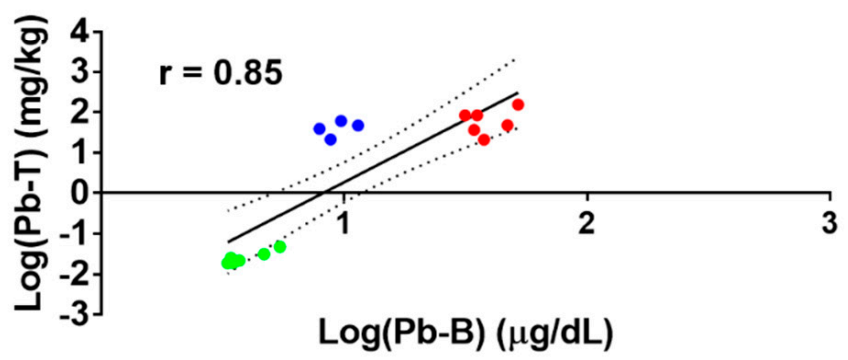

Figure 4. Pearson's correlations showing the relationship between log-transformed $\mathrm{Pb}-\mathrm{B}$ and $\mathrm{Pb}-\mathrm{T}$ crown and root of the lower and upper incisors in the laboratory Pb-exposed Sprague Dawley rats. (A) lower incisor (L1) Pb-B versus Pb-T $(r=0.91, p<0.01$ ); (B) lower incisor (L2) $\mathrm{Pb}-\mathrm{B}$ versus $\mathrm{Pb}-\mathrm{T}(r=0.82, p<0.01)$; (C) upper incisor (U1) Pb-B versus $\mathrm{Pb}-\mathrm{T}(r=0.91, p<0.01)$ and (D) upper incisor (U2) Pb-B Vs Pb-T $(r=0.85, p<0.01)$.

\subsection{Lead in Blood and Teeth and Their Relationship in the Lead-Exposed R. rattus Rats}

Figure 5A shows the $\mathrm{Pb}-\mathrm{B}$ in wild rats sampled from different sites within varying distances from the closed $\mathrm{Pb}-\mathrm{Zn}$ mine as a reference point as shown in Figure 1. The accumulation of $\mathrm{Pb}$ - $\mathrm{B}$ differed significantly among the sites with the highest $\mathrm{Pb}-\mathrm{B}$ levels seen in rat samples captured closer to the old mine and lowest in rat samples collected furthest from the mine (Figure 5A). Quantitatively, the $\mathrm{CH}$ site group had a mean $\mathrm{Pb}-\mathrm{B}$ of $245.40 \pm 161.90 \mu \mathrm{g} / \mathrm{dL}$, the MW site group had $213.20 \pm 14.22 \mu \mathrm{g} / \mathrm{dL}$, the MK site group had $40.11 \pm 15.56 \mu \mathrm{g} / \mathrm{dL}$ and the LK site group had $15.60 \pm 0.99 \mu \mathrm{g} / \mathrm{dL}$. Furthermore, in reference to the control site sample ( $\mathrm{LK})$, the $\mathrm{Pb}-\mathrm{B}$ levels in known contaminated sites were significantly higher in MK $(p<0.05)$, MW $(p<0.01)$, and $\mathrm{CH}(p<0.01)$ groups. No difference in $\mathrm{Pb}-\mathrm{B}$ levels in the $\mathrm{CH}$ and $\mathrm{MW}$ groups was observed (Figure 5A).

Figure $5 \mathrm{~B}$ shows the accumulation pattern of $\mathrm{Pb}-\mathrm{T}$ in the crown part of the lower incisor (L2) of $R$. rattus rats exposed to $\mathrm{Pb}$ in their natural environment. Because an application of our laboratory results showed a higher $\mathrm{Pb}$ level in the L2 section compared to the L1 section of incisors (Figure 3B,C), only L2 Pb levels in $R$. rattus rats are shown. The accumulation $\mathrm{Pb}-\mathrm{T}$ was higher in the rats that were captured closer to the closed $\mathrm{Pb}-\mathrm{Zn}$ mine had higher $\mathrm{Pb}-\mathrm{T}$ levels than those captured further away from the closed $\mathrm{Pb}-\mathrm{Zn}$ mine. Quantitatively, the $\mathrm{CH}$ group had the highest levels with Pb-T of $383.60 \pm 144.10 \mathrm{mg} / \mathrm{kg}$, followed by MW group with Pb-T of $102.60 \pm 91.60 \mathrm{mg} / \mathrm{kg}$, MK with $32.66 \pm 8.02 \mathrm{mg} / \mathrm{kg}$, and the least $\mathrm{Pb}-\mathrm{T}$ was in the LK group with $3.17 \pm 1.69 \mathrm{mg} / \mathrm{kg}$. The Pb-T concentrations among the groups were statistically significant $(p<0.05)$, as shown by lower case letters (Figure 5B). In addition, the exposed groups were significantly different from the assigned control (LK) group $(p<0.01)$. In the present study, the Pearson's correlation analysis between $\mathrm{Pb}-\mathrm{B}$ and $\mathrm{Pb}-\mathrm{T}$ of log-transformed data in the crown of lower incisors in wild rats exposed to $\mathrm{Pb}$ was positive $(r=0.85, p<0.01)$, as shown (Figure $5 \mathrm{C}$ ). 


\section{A. blood $\mathrm{Pb}$ in $R$. rattus}

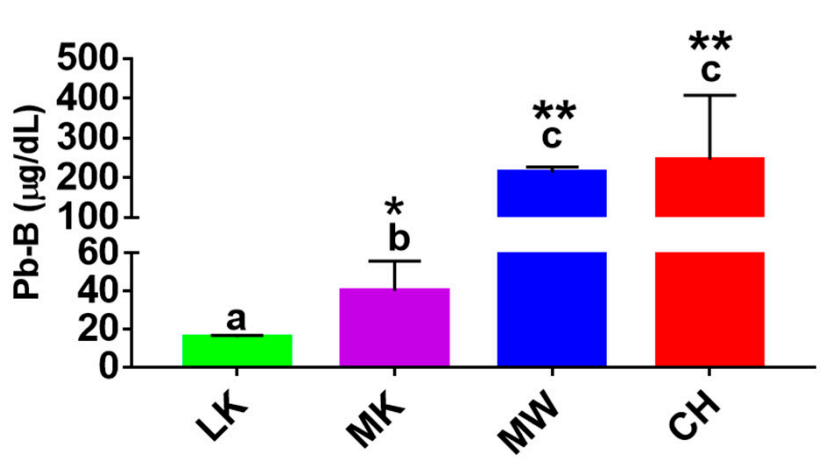

B. Teeth $\mathrm{Pb}$ - lower incisors (L2)

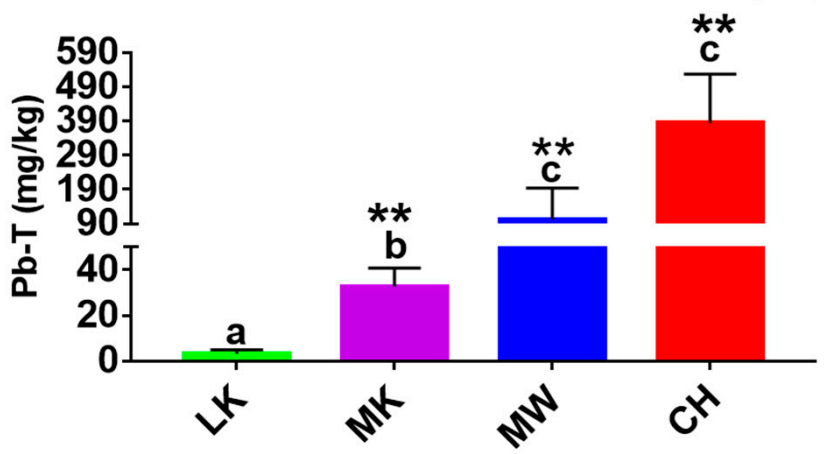

\section{Blood Vs Teeth Pb - (L2)}

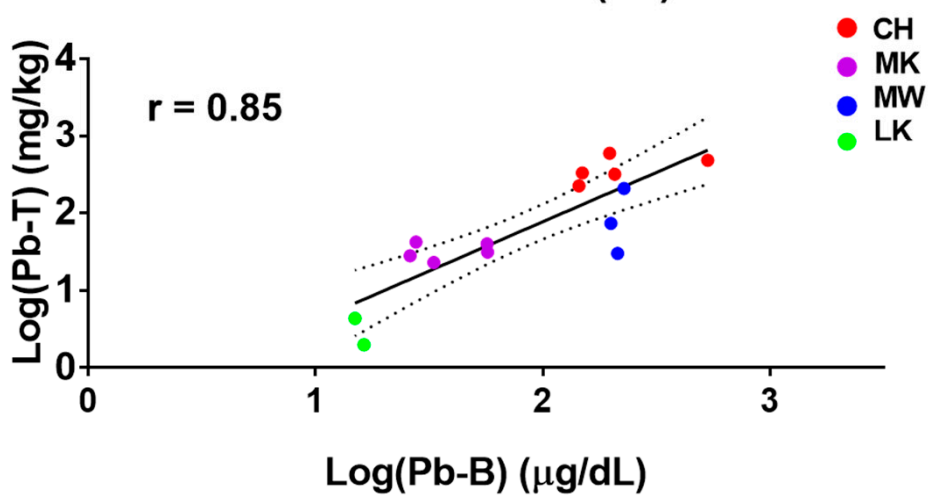

Figure 5. Mean $\pm \mathrm{SD}$ of $\mathrm{Pb}-\mathrm{B}$ and $\mathrm{Pb}-\mathrm{T}$ of $\mathrm{Pb}$-exposed $R$. rattus rats. (A) $\mathrm{Pb}$ - $\mathrm{B}$ from rats sampled from Lukanga (LK; $n=2)$; Makululu (MK; $n=5)$; Mutwe Wansofu (MW; $n=3)$ and Chowa $(\mathrm{CH} ; n=5)$. (B) Pb-T from rats sampled from LK $(n=2)$; MK $(n=5)$; MW $(n=3)$, and CH $(n=5)$; The lower case letters $\mathrm{a}, \mathrm{b}$, and c represent significant differences among the groups using the Tukey's multiple comparison test $(p<0.05)$. For the both $\mathrm{Pb}-\mathrm{B}$ and the $\mathrm{Pb}-\mathrm{T},{ }^{*}$ at $p<0.05$ and ${ }^{* *}$ at $p<0.01$ represent significant difference between the LK site (control group) and other groups sampled closer to the former Pb- $\mathrm{Zn}$ mine using the Turkey's test. (C) Log-transformed Pearson's correlations of Pb-B versus Pb-T in $R$. rattus rats $(r=0.85, p<0.01)$.

3.4. Lead Distribution in the Incisor Teeth of the Lead-Exposed Laboratory Sprague Dawley and Wild R. rattus Rats Using LA-ICP-MS

The local distribution of the $\mathrm{Pb}$ mappings using LA-ICP-MS in the incisor teeth of both laboratory and wild rats exposed to $\mathrm{Pb}$ is shown in Figure $6 \mathrm{~A}, \mathrm{~B}$, respectively. A homogenous distribution of $\mathrm{Pb}$ was observed in the greater portion of the tooth from the root extending to the pulp and the dentine in both laboratory and wild rodent teeth samples (Figure 6A,B). On the other hand, an inhomogeneous distribution of $\mathrm{Pb}$ was found in the surface enamel near the tip of the incisor crown having an intense localized distribution of $\mathrm{Pb}$. The distribution of $\mathrm{Pb}$ in both laboratory and wild rodent teeth was similar (Figure 6A,B). 

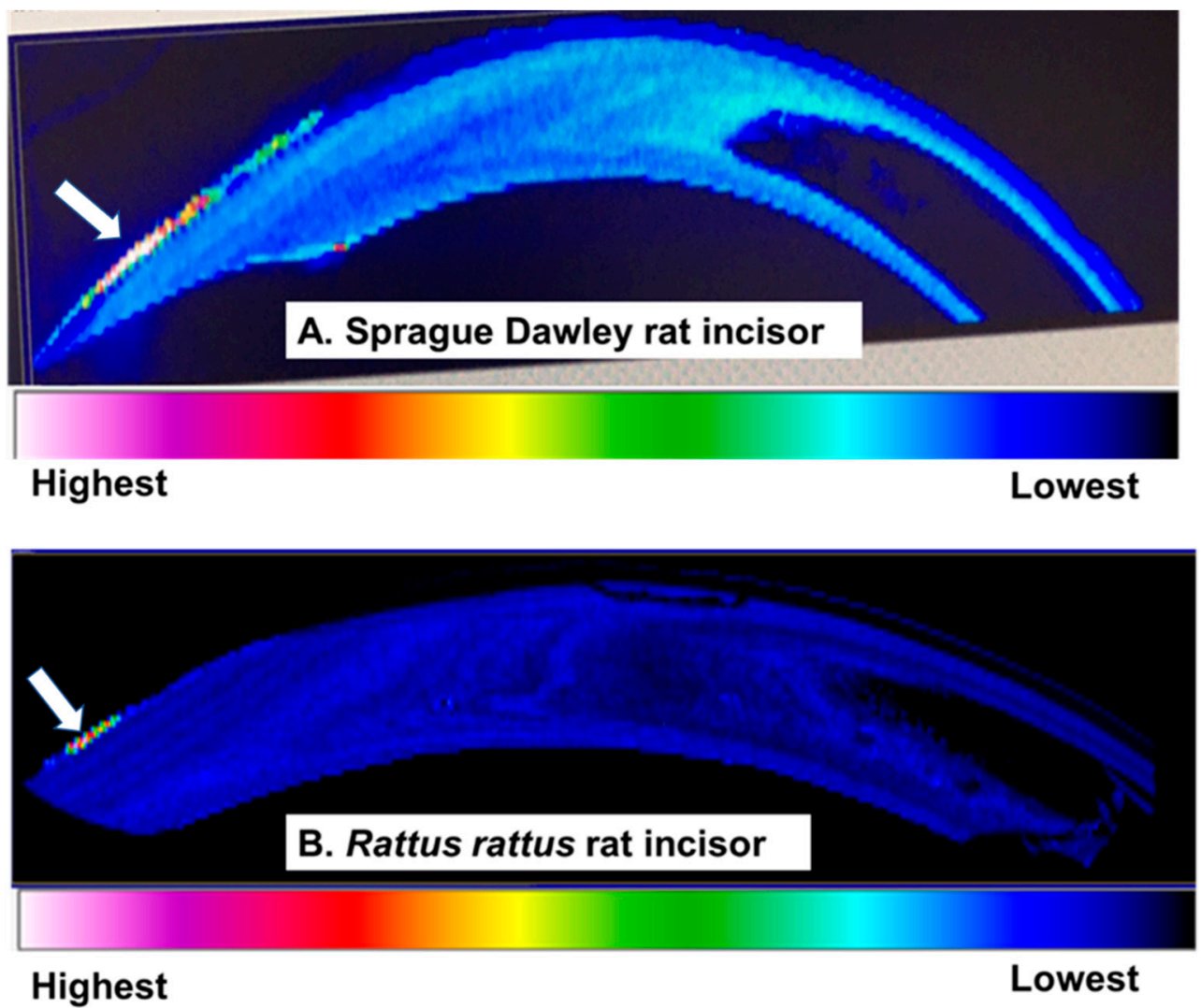

Figure 6. $\mathrm{Pb}$ distribution in the incisor teeth of the lead-exposed laboratory Sprague Dawley and wild exposed (R. rattus) rats using LA-ICP-MS. Homogenous distribution of $\mathrm{Pb}$ in the pulp and dentine of the with inhomogeneous distribution of $\mathrm{Pb}$ - $\mathrm{T}$ characterized by intense deposits of $\mathrm{Pb}$ in the exterior enamel (arrow). (A) Sprague Dawley and (B) R. rattus rats in incisors.

\section{Discussion}

The present study focused on $\mathrm{Pb}$ quantities in the rodent incisor tooth as a biomarker of $\mathrm{Pb}$ and its applicability in $\mathrm{Pb}$ exposure screening. The most striking observation was the high accumulation of $\mathrm{Pb}$ - $\mathrm{T}$ in the crown of the upper and lower incisor teeth than the roots across all levels of exposure in laboratory Pb-exposed Sprague Dawley rats. The inherent incisor tooth structural variations between the root and crown due to the larger part of the dental root pulp and higher dentine crown mass, as well as dentine-enamel ratio, could be the key factors in the accumulation of $\mathrm{Pb}-\mathrm{T}$ differences [33]. The rodent incisors are predominantly dentine with a thin layer of enamel located only in the front part of the tooth [30]. The influence of the presence of the large dentine mass in the crown of incisor teeth may have been one of the contributing factors behind the L2 or U2 in the low $\mathrm{Pb}$ group accumulating much $\mathrm{Pb}$ than the $\mathrm{L} 1$ or $\mathrm{U} 1$ in the high $\mathrm{Pb}$ exposure group. The current findings seem to agree with other studies that demonstrated that $\mathrm{Pb}$ is highly accumulated in the dentine part of the teeth [14,34-36].

$\mathrm{The} \mathrm{Pb}-\mathrm{T}$ in both the root and the crown of the lower incisors and upper incisor teeth and the $\mathrm{Pb}-\mathrm{B}$ accumulation in the Sprague Dawley rats following laboratory exposure were in a $\mathrm{Pb}$ dose-dependent pattern. These findings suggest that rodent incisors could be a useful indicator of exposure to $\mathrm{Pb}$, as was reported in goats [34] and rats [16]. Furthermore, strong positive correlations between $\mathrm{Pb}-\mathrm{B}$ and $\mathrm{Pb}-\mathrm{T}$ were found in the $\mathrm{Pb}$-exposed laboratory rats, similar to what has been reported in humans [33,37]. Taken together, our results in the laboratory $\mathrm{Pb}$-exposed Sprague Dawley rats showed that $\mathrm{Pb}-\mathrm{T}$ in the crown incisor analysis may provide some advantages in assessing $\mathrm{Pb}$ exposure.

In the $R$. rattus rat species that were used as sentinel animals around the closed $\mathrm{Pb}-\mathrm{Zn}$ mine in Kabwe, Zambia, the accumulation of $\mathrm{Pb}-\mathrm{T}$ in $\mathrm{L} 2$ and $\mathrm{Pb}-\mathrm{B}$ were linked to the 
distance in reference to the point source. Moreover, there was a strong positive correlation between $\mathrm{Pb}-\mathrm{T}$ in $\mathrm{L} 2$ and $\mathrm{Pb}-\mathrm{B}$ in the wild of rats, suggesting that the incisor crown would be a good predictor of $\mathrm{Pb}$ exposure just like $\mathrm{Pb}$ in blood. This was in agreement with the pattern of $\mathrm{Pb}-\mathrm{T}$ accumulation reported in deciduous teeth of children living near a lead-acid battery smelter [38]. Comparatively, our results were also in tandem with surface enamel $\mathrm{Pb}$ - $\mathrm{T}$ in children, where much $\mathrm{Pb}-\mathrm{T}$ accumulation was reported in polluted areas than in less polluted areas [39]. Furthermore, the $\mathrm{Pb}-\mathrm{T}$ in the crown of the sentinel rats in the present study corroborated the findings of $\mathrm{Pb}$ concentrations in soils [25], and $\mathrm{Pb}-\mathrm{B}$ in free-roaming dogs [40] and free-range chickens [41] sampled within the vicinity of the former $\mathrm{Pb}-\mathrm{Zn}$ mine. Taken together, the current findings indicate that the rodent tooth incisor crown may be a useful tool for environmental $\mathrm{Pb}$ exposure monitoring.

$\mathrm{The} \mathrm{Pb}-\mathrm{T}$ in the crown incisors were relatively higher than the $\mathrm{Pb}-\mathrm{B}$, corroborating reports that indicated that $\mathrm{Pb}-\mathrm{T}$ were better indicator exposure and cumulative $\mathrm{Pb}$ body burden than $\mathrm{Pb}-\mathrm{B}$ [42]. The high $\mathrm{Pb}-\mathrm{B}$ levels observed in wild rats were however not surprising because they were recorded from the Chowa and Mutwe Wansofu sampling sites that were near to the mine where children with very high $\mathrm{Pb}-\mathrm{B}$ were previously reported [4]. On the other hand, we observed that the lower the Pb-B level, the lower the $\mathrm{Pb}-\mathrm{T}$, which adds further merits to the use of $\mathrm{L} 2$ sample as a biomarker of exposure. While the duration of exposure in wild rats (R. rattus) may not be clearly known, findings in the laboratory $\mathrm{Pb}$ exposed rats that were exposed for eight weeks suggest that the teeth may be useful both for chronic $\mathrm{Pb}$ exposure and in sub-chronic conditions exposure where blood levels are elevated.

The $\mathrm{Pb}$ - $\mathrm{T}$ distribution mapping using LA-ICP-MS in the lower incisors of the $\mathrm{Pb}$ exposed laboratory and wild rats was performed for the first time. Interestingly, the distribution of $\mathrm{Pb}-\mathrm{T}$ was homogeneously distributed in the dental pulp, dentine, and the greater part of enamel except on the front tip part of the incisor crown with enamel in both laboratory and wild rats. The intense $\mathrm{Pb}$ localization seen on the tip of the incisor crown with an enamel surface was in contrast to other studies that demonstrated that calcified tissue layers in direct contact or in proximity to vascular tissues accumulated much more $\mathrm{Pb}$ than those further away in bones [29] and teeth around the circumpulpal dentine $[18,34,43]$. However, the present findings agreed in part with a report in human incisor teeth samples where most of the $\mathrm{Pb}$ were primarily deposited in the secondary dentine region close to the pulp, and secondarily, at surface enamel [12]. Moreover, the observed high intensities of $\mathrm{Pb}$ in the outer part of incisors were only on the front side, the only side bearing enamel in rodent incisors [30]. This phenomenon has been demonstrated in both erupted and non-erupted teeth that highly accumulated $\mathrm{Pb}$ in the outer enamel surface and with a gradual reduction of $\mathrm{Pb}$ in the deeper layers of the enamel $[19,39,44,45]$. Taken together, the characteristic enamel surface $\mathrm{Pb}$ accumulation in the crown incisors further supports the use of the crown incisor as an alternative biomarker of $\mathrm{Pb}$ exposure screening in wild and laboratory rats, with the former having merits for use as a sentinel marker of exposure.

The current study limitation bordered around wild rats sampling. The small number of samples for the LK $(n=2)$ and MW $(n=3)$ after the exclusion of other species after genomic sequencing except the $R$. rattus species is the notable limitation. The logistics and travel restrictions could not permit re-sampling to increase the sample size of the $R$. rattus. Further validation of the rat incisor crown as a suitable alternative biomarker to blood- $\mathrm{Pb}$ for environmental $\mathrm{Pb}$ exposure assessment with a much larger sample size is recommended. Notwithstanding, the current study has revealed that the crown subdivision of the incisor rodents could be a suitable biomarker of $\mathrm{Pb}$ exposure. The use of the incisor crown subdivision has merits because it is easy to extract and is stable for preservation purposes [10]. Besides, the inherent advantage of teeth over the blood sample matrix in its ability to retain $\mathrm{Pb}$ after a month or more after the source is removed makes it an attractive alternative biomarker of $\mathrm{Pb}$ exposure. In the current study, wild rodents were trapped from residential areas, and sometimes in houses, making them suitable sentinel markers for 
human exposure, especially children with hand-to-mouth activities. Furthermore, targeting the crown incisor for $\mathrm{Pb}$ exposure assessment without targeting the whole incisor tooth will maximize time, resources, and increase the chances of detection of $\mathrm{Pb}$ in sentinel wild rats.

\section{Conclusions}

The crown and the root of both lower and upper incisor teeth $\mathrm{Pb}-\mathrm{T}$ in laboratory $\mathrm{Pb}$ exposed Sprague Dawley rats accumulated $\mathrm{Pb}$ in a dose-dependent manner with the crown accumulating much more $\mathrm{Pb}-\mathrm{T}$ than the root, suggesting that the crown may be a superior marker of $\mathrm{Pb}$ exposure than the root. Furthermore, the $\mathrm{Pb}-\mathrm{T}$ accumulation in the crown of the lower incisors (L2) of wild rats discriminated the varying distances of sampling sites in relation to the $\mathrm{Pb}-\mathrm{Zn}$ mine point source in $\mathrm{Pb}$ exposed $\mathrm{R}$. rattus rats. In addition, the strong positive correlations between $\mathrm{Pb}-\mathrm{B}$ and $\mathrm{Pb}$ - $\mathrm{T}$ observed in both laboratory and wild rats exposed to $\mathrm{Pb}$ support the possibility of rodent teeth as a useful tool for environmental assessment of $\mathrm{Pb}$ exposure. The high $\mathrm{Pb}-\mathrm{T}$ in the crown compared to the root and the highly localized distribution of $\mathrm{Pb}$ in the incisor crown bearing enamel, as observed from the LA-ICP-MS mapping, indicate that the crown subdivision of the incisor tooth may be adequate for its use in sentinel rodents for $\mathrm{Pb}$ exposure assessment. Further studies are required to validate the rat incisor crown as a suitable alternative biomarker to blood- $\mathrm{Pb}$ for environmental $\mathrm{Pb}$ exposure assessment.

Supplementary Materials: The following are available online at https://www.mdpi.com/1660-4 601/18/2/767/s1, Table S1: Wild rat species, Table S2: Microwave operating conditions for teeth and blood digestion, Table S3: Detailed analytical conditions of ICP-MS, Table S4: Detailed analytical conditions of LA-ICP-MS.

Author Contributions: Conceptualization, A.K. (Andrew Kataba) and S.M.M.N.; methodology, A.K. (Andrew Kataba)., H.T. and S.M.M.N.; software, A.K. (Ayano Kubota) and T.M.; validation, A.K. (Andrew Kataba)., H.T. and S.M.M.N.; formal analysis A.K. (Andrew Kataba); investigation, A.K. (Andrew Kataba), S.M.M.N., H.N., H.T., Y.B.Y., J.Y., K.M. and G.Z.; resources, S.M.M.N., K.Y., Y.I. and M.I.; data curation, A.K. (Andrew Kataba), A.K. (Ayano Kubota) and T.M.; writing—original draft preparation, A.K. (Andrew Kataba); writing-review and editing, S.M.M.N., H.N., H.T., Y.B.Y., J.Y., K.M. and G.Z.; visualization, A.K. (Andrew Kataba), A.K. (Ayano Kubota) and T.M.; supervision, S.M.M.N., K.Y., Y.I. and M.I.; project administration, K.Y. and M.I.; funding acquisition, S.M.M.N., K.Y., Y.I. and M.I. All authors have read and agreed to the published version of the manuscript.

Funding: The current work was supported by Grants-in-Aid for Scientific Research from the Ministry of Education, Culture, Sports, Science and Technology of Japan awarded to M. Ishizuka (No. 16H01779, 18K19847, 18KK0287) and Y. Ikenaka (17K20038, 18H04132) and S.M.M. Nakayama (No. 17KK0009, 20K20633) and K. Yokoyama (19H01081), and the foundation of JSPS Bilateral Open Partnership Joint Research Projects (JPJSBP120209902), the Japan Prize Foundation and Hokkaido University SOUSEI Support Program for Young Researchers in FY2020 (SMMN). This research was equally supported by JST/JICA SATREPS (Science and Technology Research Partnership for Sustainable Development; No. JPMJSA1501), aXis (Accelerating Social Implementation for SDGs Achievement No. JPMJAS2001) funded by JST as well as Program for supporting introduction of the new sharing system (JPMXS0420100619).

Institutional Review Board Statement: “Not applicable" for studies not involving humans or animals.

Informed Consent Statement: "Not applicable" for studies not involving humans.

Data Availability Statement: The datasets generated and analyzed during the current study are are available from the corresponding author on reasonable request.

Acknowledgments: The analyses were technically supported by Takahiro Ichise and Nagisa Hirano (Faculty of Veterinary Medicine, Hokkaido University) as well as by Kosuke Nakamura and Hidehiko Nomura (Faculty of Science, Hokkaido University).

Conflicts of Interest: The authors declare no conflict of interest. 


\section{Appendix A. Wild Rat Species Identification}

The species of the wild rats sampled were identified using genomic DNA sequencing. Genomic DNA was extracted from liver samples of wild rodents with Wizard ${ }^{\circledR}$ Genomic DNA Purification Kit (Promega Corporation Madison, WI, USA). Species discrimination was done following a slight modification of the method described by Robins et al. [24]. To amplify Cytochrome b, 762 bp (Cyt-b) gene with accession number: JX887164.1, the primers used were Forward primer (5'-GGTGAAGGCTTCAACGCCAACCCTA-3') and Reverse primer ( $5^{\prime}$-TAGAATATCAGCTTTGGGTGTTGATGG-3'). The polymerase chain reaction (PCR) thermal regime for all amplifications was one initial denaturation step of $94{ }^{\circ} \mathrm{C}$ for 2 min and 35 cycles of denaturation at $94^{\circ} \mathrm{C}$ for $30 \mathrm{~min}$, annealing at $60^{\circ} \mathrm{C}$ for $30 \mathrm{~min}$ and extension at $72{ }^{\circ} \mathrm{C}$ for $1 \mathrm{~min}$; and a final extension step of $72{ }^{\circ} \mathrm{C}$ for 6 min with a thermal cycler (iCycler, Bio-Rad, Hercules, CA, USA) and EmeraldAmp MAX PCR Master Mix (Takara Bio Inc., Shiga, Japan). The volume of PCR mix was $10 \mu \mathrm{L}$ containing in $50 \mathrm{ng}$ genomic DNA, $5 \mu \mathrm{L}$ of EmeraldAmp MAX PCR Master Mix and $0.2 \mu \mathrm{M}$ of each forward and reverse primer. The amplified products were purified by QIAquick ${ }^{\circledR}$ PCR Purification kit (Qiagen, Hilden, Germany). The sequence reaction was done by Fasmac Co. Ltd. (Kanagawa, Japan). From these sequences done by Fasmac Co. Ltd., the rat species were identified through blast analysis using the National Center for Biotechology Information (NCBI) website. Based on the results 15 Rattus rattus rats in total were identified and used for the study. And from each sampling site, the following numbers of paired blood and lower incisors teeth of $R$. rattus rats in brackets were included in the study, namely, Lukanga (LK) $(n=2)$; Mutwe Wansofu (MW) $(n=3)$; Chowa (CH) $(n=5)$; and Makululu (MK) $(n=5)$, respectively (Table S1).

\section{References}

1. Galal, M.K.; Elleithy, E.M.; Abdrabou, M.I.; Yasin, N.A.; Shaheen, Y.M. Modulation of caspase-3 gene expression and protective effects of garlic and spirulina against CNS neurotoxicity induced by lead exposure in male rats. NeuroToxicology 2019, 72, 15-28. [CrossRef] [PubMed]

2. Dapul, H.; Laraque, D. Lead Poisoning in Children. Adv. Pediatr. 2014, 61, 313-333. [CrossRef] [PubMed]

3. Bose-O'Reilly, S.; Yabe, J.; Makumba, J.; Schutzmeier, P.; Ericson, B.; Caravanos, J. Lead intoxicated children in Kabwe, Zambia. Environ. Res. 2018, 165, 420-424. [CrossRef] [PubMed]

4. Yabe, J.; Nakayama, S.; Ikenaka, Y.; Yohannes, Y.B.; Bortey-Sam, N.; Oroszlany, B.; Muzandu, K.; Choongo, K.; Kabalo, A.N.; Ntapisha, J.; et al. Lead poisoning in children from townships in the vicinity of a lead-zinc mine in Kabwe, Zambia. Chemosphere 2015, 119, 941-947. [CrossRef]

5. Yabe, J.; Nakayama, S.M.; Nakata, H.; Toyomaki, H.; Yohannes, Y.B.; Muzandu, K.; Kataba, A.; Zyambo, G.; Hiwatari, M.; Narita, D.; et al. Current trends of blood lead levels, distribution patterns and exposure variations among household members in Kabwe, Zambia. Chemosphere 2020, 243, 125412. [CrossRef]

6. Dooyema, C.A.; Neri, A.; Lo, Y.; Durant, J.; Dargan, P.I.; Swarthout, T.; Biya, O.; Gidado, S.O.; Haladu, S.; Sani-Gwarzo, N.; et al. Outbreak of Fatal Childhood Lead Poisoning Related to Artisanal Gold Mining in Northwestern Nigeria, 2010. Environ. Health Perspect. 2012, 120, 601-607. [CrossRef]

7. Haeflinger, P.; Mathieu-Nolf, M.; Lociciro, S.; Ndiaye, C.; Coly, M.; Diouf, A.; Faye, L.A.; Sow, A.; Tempowski, J.; Pronczuk, J.; et al. Mass Lead Intoxication from Informal Used Lead-Acid Battery Recycling in Darkar, Senegal. Environ. Health Perspect. $2009,117$. [CrossRef]

8. Bellinger, D.C. Childhood Lead Exposure and Adult Outcomes. JAMA 2017, 317, 1219-1220. [CrossRef]

9. Chang, S.-H.; Cheng, B.-H.; Lee, S.-L.; Chuang, H.-Y.; Yang, C.-Y.; Sung, F.-C.; Wu, T.-N. Low blood lead concentration in association with infertility in women. Environ. Res. 2006, 101, 380-386. [CrossRef]

10. Barbosa, F.; Tanus-Santos, J.E.; Gerlach, R.F.; Parsons, P.J. A Critical Review of Biomarkers Used for Monitoring Human Exposure to Lead: Advantages, Limitations, and Future Needs. Environ. Health Perspect. 2005, 113, 1669-1674. [CrossRef]

11. De Figueiredo, F.A.T.; Ramos, J.; Kawakita, E.R.H.; Bilal, A.S.; De Sousa, F.B.; Swaim, W.D.; Issa, J.P.M.; Gerlach, R.F. Lead line in rodents: An old sign of lead intoxication turned into a new method for environmental surveillance. Environ. Sci. Pollut. Res. 2016, 23, 21475-21484. [CrossRef] [PubMed]

12. Wang, Y.; Specht, A.J.; Liu, Y.; Finney, L.; Maxey, E.; Vogt, S.; Zheng, W.; Weisskopf, M.; Nie, L.H. Microdistribution of lead in human teeth using microbeam synchrotron radiation X-ray fluorescence ( $\mu$-SRXRF). X-ray Spectrom. 2016, 46, 19-26. [CrossRef] [PubMed]

13. Rossi, E. Low Level Environmental Lead Exposure-A Continuing Challenge. Clin. Biochem. Rev. 2008, 29, 63-70. [PubMed]

14. Steenhout, A.; Pourtois, M. Lead accumulation in teeth as a function of age with different exposures. Occup. Environ. Med. 1981, 38, 297-303. [CrossRef] [PubMed] 
15. Winneke, G.; Hrdina, K.-G.; Brockhaus, A. Neuropsychological studies in children with elevated tooth-lead concentrations. Int. Arch. Occup. Environ. Health 1982, 51, 169-183. [CrossRef]

16. Arora, M.; Hare, D.J. Tooth lead levels as an estimate of lead body burden in rats following pre- and neonatal exposure. RSC Adv. 2015, 5, 67308-67314. [CrossRef]

17. Evans, R.D.; Richner, P.; Outridge, P.M. Micro-spatial variations of heavy metals in the teeth of walrus as determined by laser ablation ICP-MS: The potential for reconstructing a history of metal exposure. Arch. Environ. Contam. Toxicol. 1995, $28,55-60$. [CrossRef]

18. Cox, A.; Keenan, F.; Cooke, M.; Appleton, J. Trace element profiling of dental tissues using laser ablation-inductively coupled plasma-mass spectrometry. Anal. Bioanal. Chem. 1996, 354, 254-258. [CrossRef]

19. Uryu, T.; Yoshinaga, J.; Yanagisawa, Y.; Endo, M.; Takahashi, J. Analysis of Lead in Tooth Enamel by Laser Ablation-Inductively Coupled Plasma-Mass Spectrometry. Anal. Sci. 2003, 19, 1413-1416. [CrossRef]

20. Yohannes, Y.B.; Ikenaka, Y.; Ito, G.; Nakayama, S.M.M.; Mizukawa, H.; Wepener, V.; Smit, N.J.; Van Vuren, J.H.J.; Ishizuka, M. Assessment of DDT contamination in house rat as a possible bioindicator in DDT-sprayed areas from Ethiopia and South Africa. Environ. Sci. Pollut. Res. 2017, 24, 23763-23770. [CrossRef]

21. Ardizzone, M.; Vizio, C.; Bozzetta, E.; Pezzolato, M.; Meistro, S.; Dondo, A.; Giorgi, I.; Seghesio, A.; Mirabelli, D.; Capella, S.; et al. The wild rat as sentinel animal in the environmental risk assessment of asbestos pollution: A pilot study. Sci. Total Environ. 2014, 479, 31-38. [CrossRef]

22. Martiniakova, M.; Omelka, R.; Jančová, A.; Stawarz, R.; Formicki, G. Concentrations of Selected Heavy Metals in Bones and Femoral Bone Structure of Bank (Myodes glareolus) and Common (Microtus arvalis) Voles from Different Polluted Biotopes in Slovakia. Arch. Environ. Contam. Toxicol. 2011, 60, 524-532. [CrossRef]

23. Togao, M.; Nakayama, S.; Ikenaka, Y.; Mizukawa, H.; Makino, Y.; Kubota, A.; Matsukawa, T.; Yokoyama, K.; Hirata, T.; Ishizuka, $\mathrm{M}$. Bioimaging of $\mathrm{Pb}$ and STIM1 in mice liver, kidney and brain using Laser Ablation Inductively Coupled Plasma Mass Spectrometry (LA-ICP-MS) and immunohistochemistry. Chemosphere 2020, 238, 124581. [CrossRef]

24. Ikenaka, Y.; Nakayama, S.M.M.; Muzandu, K.; Choongo, K.; Teraoka, H.; Mizuno, N.; Ishizuka, M. Heavy Metal Contamination of Soil and Sediment in Zambia. Afr. J. Environ. Sci. Technol. 2010, 4, 729-739.

25. Nakayama, S.; Ikenaka, Y.; Hamada, K.; Muzandu, K.; Choongo, K.; Teraoka, H.; Mizuno, N.; Ishizuka, M. Metal and metalloid contamination in roadside soil and wild rats around a $\mathrm{Pb}-\mathrm{Zn}$ mine in Kabwe, Zambia. Environ. Pollut. 2011, 159, $175-181$. [CrossRef]

26. Robins, J.H.; Hingston, M.; Matisoo-Smith, E.; Ross, H.A. Identifying Rattus species using mitochondrial DNA. Mol. Ecol. Notes 2007, 7, 717-729. [CrossRef]

27. Nakata, H.; Nakayama, S.; Yabe, J.; Liazambi, A.; Mizukawa, H.; Darwish, W.S.; Ikenaka, Y.; Ishizuka, M. Reliability of stable Pb isotopes to identify $\mathrm{Pb}$ sources and verifying biological fractionation of Pb isotopes in goats and chickens. Environ. Pollut. 2016, 208, 395-403. [CrossRef]

28. Nakata, H.; Nakayama, S.M.M.; Oroszlany, B.; Ikenaka, Y.; Mizukawa, H.; Tanaka, K.; Harunari, T.; Tanikawa, T.; Darwish, W.S.; Yohannes, Y.B.; et al. Monitoring Lead (Pb) Pollution and Identifying Pb Pollution Sources in Japan Using Stable Pb Isotope Analysis with Kidneys of Wild Rats. Int. J. Environ. Res. Public Health 2017, 14, 56. [CrossRef]

29. Ishii, C.; Nakayama, S.M.; Kataba, A.; Ikenaka, Y.; Saito, K.; Watanabe, Y.; Makino, Y.; Matsukawa, T.; Kubota, A.; Yokoyama, K.; et al. Characterization and imaging of lead distribution in bones of lead-exposed birds by ICP-MS and LA-ICP-MS. Chemosphere 2018, 212, 994-1001. [CrossRef]

30. Mancinelli, E.; Capello, V. Anatomy and Disorders of the Oral Cavity of Rat-like and Squirrel-like Rodents. Veter-Clin. North Am. Exot. Anim. Pr. 2016, 19, 871-900. [CrossRef]

31. Park, M.K.; Min, S.-Y.; Song, J.S.; Lee, J.-H.; Jung, H.-S.; Kim, S.-O. Estimated Time of Biomineralization in Developing Rat Incisors. J. Korean Acad. Pedtatric Dent. 2017, 44, 138-146. [CrossRef]

32. Suzuki, T.; Sakata, S.; Makino, Y.; Obayashi, H.; Ohara, S.; Hattori, K.; Hirata, T. iQuant2: Software for Rapid and Quantitative Imaging Using Laser Ablation-ICP Mass Spectrometry. Mass Spectrom. 2018, 7, A0065. [CrossRef]

33. Rabinowitz, M. Relating tooth and blood lead levels in children. Bull. Environ. Contam. Toxicol. 1995, 55, 853-857. [CrossRef]

34. Bellis, D.J.; Hetter, K.M.; Jones, J.; Amarasiriwardena, D.; Parsons, P.J. Lead in teeth from lead-dosed goats: Microdistribution and relationship to the cumulative lead dose. Environ. Res. 2008, 106, 34-41. [CrossRef]

35. Grobler, S.; Theunissen, F.S.; Kotze, T. The relation between lead concentrations in human dental tissues and in blood. Arch. Oral Biol. 2000, 45, 607-609. [CrossRef]

36. Teeth as Indicators of Environmental Pollution with Lead. J. Environ. Anal. Toxicol. 2012, 2, 1-5. [CrossRef]

37. Barton, H.J. Advantages of the Use of Deciduous Teeth, Hair, and Blood Analysis for Lead and Cadmium Bio-Monitoring in Children. A Study of 6-Year-Old Children from Krakow (Poland). Biol. Trace Element Res. 2010, 143, 637-658. [CrossRef]

38. Johnston, J.E.; Franklin, M.; Roh, H.; Austin, C.; Arora, M. Lead and Arsenic in Shed Deciduous Teeth of Children Living Near a Lead-Acid Battery Smelter. Environ. Sci. Technol. 2019, 53, 6000-6006. [CrossRef] [PubMed]

39. De Almeida, G.R.C.; Saraiva, M.; Barbosa, F.; Krug, F.J.; Cury, J.A.; Sousa, M.D.L.R.D.; Buzalaf, M.A.R.; Gerlach, R.F. Lead contents in the surface enamel of deciduous teeth sampled in vivo from children in uncontaminated and in lead-contaminated areas. Environ. Res. 2007, 104, 337-345. [CrossRef] [PubMed] 
40. Toyomaki, H.; Yabe, J.; Nakayama, S.M.; Yohannes, Y.B.; Muzandu, K.; Liazambi, A.; Ikenaka, Y.; Kuritani, T.; Nakagawa, M.; Ishizuka, M. Factors associated with lead $(\mathrm{Pb})$ exposure on dogs around a Pb mining area, Kabwe, Zambia. Chemosphere 2020, 247, 125884. [CrossRef] [PubMed]

41. Yabe, J.; Nakayama, S.; Ikenaka, Y.; Muzandu, K.; Choongo, K.; Mainda, G.; Kabeta, M.; Ishizuka, M.; Umemura, T. Metal distribution in tissues of free-range chickens near a lead-zinc mine in Kabwe, Zambia. Environ. Toxicol. Chem. 2012, 32, 189-192. [CrossRef]

42. Hegde, S.; Sridhar, M.; Bolar, D.R.; Bhaskar, S.A.; Sanghavi, M.B. Relating tooth- and blood-lead levels in children residing near a zinc-lead smelter in India. Int. J. Paediatr. Dent. 2010, 20, 186-192. [CrossRef]

43. Hare, D.J.; Austin, C.; Doble, P.; Arora, M. Elemental bio-imaging of trace elements in teeth using laser ablation-inductively coupled plasma-mass spectrometry. J. Dent. 2011, 39, 397-403. [CrossRef]

44. Olympio, K.; Huila, M.F.; Cardoso, C.D.A.B.; Ferreira, A.P.S.D.S.; Ortiz, A.G.; Toma, H.E.; Da Silva, R.H.A.; Luz, M.S.; Cardoso, M.R.A.; Kelmer, G.A.R.; et al. Can in vivo surface dental enamelmicrobiopsies be used to measure remote lead exposure? Environ. Sci. Pollut. Res. 2017, 25, 9322-9329. [CrossRef] [PubMed]

45. Cleymaet, R.; Collys, K.; Retief, D.H.; Michotte, Y.; Slop, D.; Taghon, E.; Maex, W.; Coomans, D. Relation between lead in surface tooth enamel, blood, and saliva from children residing in the vicinity of a non-ferrous metal plant in Belgium. Occup. Environ. Med. 1991, 48, 702-709. [CrossRef] [PubMed] 